\title{
Laminin-5 offsets the efficacy of gefitinib ('Iressa') in hepatocellular carcinoma cells
}

\author{
G Giannelli, ${ }^{*}$, A Azzariti², E Fransvea', L Porcelli², S Antonaci' and A Paradiso ${ }^{2}$ \\ 'Section of Internal Medicine, Department of Internal Medicine, Immunology, and Infectious Diseases, University of Bari Medical School, Bari, Italy; \\ ${ }^{2}$ Clinical Experimental Oncology Laboratory, National Cancer Institute Bari, Italy
}

Prognosis and survival of patients with hepatocellular carcinoma ( $\mathrm{HCC})$ is still very poor, and no therapies are currently available to inhibit tumour growth and metastases. Recently, we reported that the expression of an extracellular matrix component (ECM), namely Laminin-5 (Ln-5), is directly related to poor prognosis in HCC patients. The aim of our study is to investigate the preclinical effect of gefitinib in an in vitro HCC model. We found that the $\mathrm{IC}_{50}$ of gefitinib in HCC cells ranged from 0.7 to I $0.0 \mu \mathrm{M}$, whereas $\mathrm{Ln}-5$ inhibited the activity of gefitinib in a dose-dependent manner. Complete inhibition of phosphorylated (p)-EGFR (epidermal growth factor receptor) was obtained within $6 \mathrm{~h}$ exposure to gefitinib and complete restoration of the receptor status was obtained after $24 \mathrm{~h}$. A downstream effect yields a decrease in p-Akt and p-Erk I/2. The addition of exogenous Ln-5 has no effect on p-EGFR, whereas it restores p-Erk I/2 and p-Akt. Consistently, Ln-5 induces recovery of HCC cells from Gefitinib-induced apoptosis. In conclusion, gefitinib inhibits HCC cell growth and we report for the first time that Ln-5, but not other ECM molecules, reduces the ability of gefitinib to inhibit cell growth via Akt. As patients with HCC have different Ln-5 expression levels, these results may help to better understand which patients might benefit from gefitinib treatment.

British Journal of Cancer (2004) 91, 1964-1969. doi:10.1038/sj.bjc.6602231 www.bjcancer.com

Published online 16 November 2004

(c) 2004 Cancer Research UK

Keywords: Laminin-5; HCC; gefitinib; extracellular matrix proteins; tumour growth

Hepatocellular carcinoma (HCC) is the fifth most frequent malignancy in the world and the third cause of tumour-related death. Furthermore, it is estimated that in coming years, the occurrence of HCC will increase in Western countries, due to hepatitis C virus diffusion (Bruix and Llovet, 2002). In HCC patients, prognosis and survival are still unsatisfactory mainly because of tumour recurrence and metastatic diffusion (Giannelli et al, 2002b).

The molecular mechanisms responsible for HCC spread are not yet known; however, we have recently reported that the expression of an extracellular matrix (ECM) component, namely Laminin-5 (Ln-5), is strongly associated in vivo with a more aggressive and invasive phenotype of HCC and with a worse prognosis (Giannelli et al, 2003). Ln-5, a major component of the basement membrane, plays a crucial role for epithelial cells so that its genetic absence is responsible for lethal disease (Meneguzzi et al, 1992). It promotes a number of different biological functions including adhesion, migration and scattering and it has been reported to play a role in cancer metastasis (Miyazaki et al, 1993; Baker et al, 1996; Xia et al, 1996). Integrins $\alpha 3 \beta 1$ and $\alpha 6 \beta 4$, the two main receptors for Ln-5, are highly expressed in epithelial cancer cells (reviewed in Giannelli et al, 2002a).

*Correspondence: Dr G Giannelli, Dipartimento di Clinica Medica, Immunologia e Malattie Infettive, Sezione di Medicina Interna, Policlinico, Piazza G Cesare II, 70I24 Bari, Italy; E-mail: g.giannelli@intmed.uniba.it. Revised 29 September 2004; accepted 3 October 2004; published online 16 November 2004
So far, no drugs are available to inhibit tumour growth and/or metastatic spread of HCC and current therapies are restricted to surgery, ethanol injection, radiotherapy and chemoembolisation. Recently, gefitinib ('Iressa'), an orally active epidermal growth factor receptor (EGFR) tyrosine kinase inhibitor that blocks signal pathways implicated in cancer growth and metastasis, has been successfully used in lung and colon cancer (Douglass, 2003; Haringhuizen et al, 2004; Johnson et al, 2004), where it could represent an alternative monotherapy for patients with advanced tumours (Herbst, 2003). In two large-scale Phase II trials, approximately $50 \%$ of previously treated patients with NSCLC had either an objective response or disease stabilisation following treatment with gefitinib $250 \mathrm{mg} \mathrm{day}^{-1}$ (Fukuoka et al, 2003; Kris et al, 2003). Furthermore, it has been reported to reduce tumour growth and metastasis occurrence in a xenograft HCC animal model (Matsuo et al, 2003), and in the USA a Phase II trial treating patients with HCC with gefitinib is currently underway.

The goal of our study is to investigate the potential therapeutic effect of, and the potential resistance to, gefitinib in an in vitro HCC model; in particular, we analysed gefitinib's ability to inhibit cell growth, and whether the Ln-5 ECM molecule reduced its efficacy.

\section{MATERIALS AND METHODS}

Gefitinib activity was tested on four different human HCC cell lines, in the absence and presence of Ln-5. 


\section{Reagents}

Gefitinib was kindly provided by AstraZeneca Pharmaceuticals, UK. Stock solutions were prepared at $20 \mathrm{~mm}$ in dimethyl sulphoxide (DMSO) and stored in aliquots at $-20^{\circ} \mathrm{C}$. Purified Ln-5 was prepared as previously described (Koshikawa et al, 2000). Working dilutions were made in culture medium supplemented with $10 \%$ fetal bovine serum, $2 \mathrm{~mm}$ glutamine, $50000 \mathrm{UL}^{-1}$ penicillin and $80 \mu \mathrm{M}$ streptomycin.

Laminin-1 (Ln-1) and Collagen IV (Coll IV) were purchased from Sigma Chemical Company (St Louis, MI, USA), Coll I from BD Biosciences (Bedford, MA, USA), Fibronectin (Fn) from Calbiochem (La Jolla, CA, USA), Fibrinogen (Fg) and Vitronectin (Vn) were gifted by Dr Felding-Habermann (TSRI, La Jolla, CA, USA) (Felding-Habermann et al, 2002).

\section{Cell culture}

Alexander, HepG2, HLF and Sk-Hep1 human HCC cell lines were routinely cultured in RPMI or DMEM medium supplemented with $10 \%$ fetal bovine serum ( $2 \mathrm{~mm}$ glutamine, $50000 \mathrm{UL}^{-1}$ penicillin and $80 \mu \mathrm{m}$ streptomycin) in a humidified incubator at $37^{\circ} \mathrm{C}$ with an atmosphere containing $5 \% \mathrm{CO}_{2}$. Cells were trypsinised once a week with trypsin/ethylenediaminetetraacetic acid (EDTA) $(0.25 \% /$ $0.02 \%$ ) and the medium was changed twice a week (Giannelli et al, 2001).

\section{Antibodies}

Antiphosphotyrosine polyclonal antibody PY99 was purchased from Santa Cruz Biotechnology, USA; anti-EGFR monoclonal antibody from Becton-Dickinson (San Diego, CA, USA) and the following monoclonal antibodies were from Cell Signaling (USA): anti-Akt, anti-phosphoAKT, anti-ERK1/2 and anti-phospho-ERK1/ 2. Mouse and rabbit horseradish peroxidase (Amersham Pharmacia Biotech, Upsala, Sweden) were used as secondary antibodies.

Anti- $\alpha 3$ and anti- $\alpha 6$ integrin blocking antibodies were purchased from Gibco (Gaithersburg, MA, USA) and from Pharmingen (San Diego, CA, USA).

\section{Cytotoxicity assay}

Gefitinib determination of $\mathrm{IC}_{50}$ was performed using the 3-[4,5dimethylthiazol-2-yl]-2,5-diphenyltetrazoliumbromide (MTT) assay. Briefly, 7500 cells in a volume of $200 \mu \mathrm{l}$ were plated in each well on a 96-well plate. After $24 \mathrm{~h}$, cells were challenged for 3 days with gefitinib at the following concentrations: $0.01,0.1,0.5,1.0,5.0$, 10.0 and $50.0 \mu \mathrm{M}$. Each experiment was reproduced in seven different wells, and each experiment repeated at least three times. Results were expressed as a dose-response curve with a plot of the fraction of unaffected (surviving) cells $v s$ the drug concentration. $\mathrm{IC}_{50}$ was defined as the drug concentration yielding $50 \%$ of affected (nonsurviving) cells compared with untreated controls. In some experiments, Ln-1, Ln-5, Coll IV, Coll I, Fg, Fn and Vn $\left(1 \mu \mathrm{g} \mathrm{ml}^{-1}\right)$ were added to cells in the presence of gefitinib $\mathrm{IC}_{50}$ and the cell growth inhibition was measured by the MTT assay. Ln-5 was also tested at different concentrations (ranging from 0.3 up to $3.0 \mu \mathrm{g} \mathrm{ml}^{-1}$ ).

Anti- $\alpha 3$ and anti- $\alpha 6$ integrin-blocking antibodies $\left(30 \mu \mathrm{g} \mathrm{ml}^{-1}\right)$ were added together with $\mathrm{Ln}-5$ in the presence of gefitinib $\mathrm{IC}_{50}$ and the cell growth inhibition was measured by the MTT assay.

\section{Western blot analysis}

Protein samples were extracted from gefitinib $\left(\mathrm{IC}_{50}\right)$ - and/or Ln-5 $\left(1 \mu \mathrm{g} \mathrm{ml}^{-1}\right)$-treated cells $\left(3 \times 10^{6}\right.$ cells $)$ after homogenisation in RIPA buffer $(0.5 \mathrm{M} \mathrm{NaCl}, 1 \%$ Triton X-100, $0.5 \%$ NP40, $1 \%$ deoxycolic acid, $3.5 \mathrm{~mm}$ sodium dodecyl sulphate (SDS), $8.3 \mathrm{~mm}$
Tris $\mathrm{HCl} \mathrm{pH} \mathrm{7.4,} 1.6 \mathrm{~mm}$ Tris base) and treated with a $20 \%$ protease inhibitor cocktail (Sigma, MO, USA). Protein concentration was determined by the Bradford method, samples were normalised for protein concentration $(25-50 \mu \mathrm{g})$, and electrophorised on $10-$ $12.5 \%$ SDS - PAGE. The signal was detected by the chemoluminescence assay (ECL-Plus, Amersham Life Science, UK) and the expression level was calculated by densitometric analysis using Multi-Analyst software (Biorad, Hercules, CA, USA), using $\beta$-actin expression as internal standard.

\section{Immunoprecipitation analysis}

HCC cells $\left(3 \times 10^{6}\right)$ were treated with gefitinib $\left(\mathrm{IC}_{50}\right)$ and/or Ln-5 $\left(1 \mu \mathrm{g} \mathrm{ml}^{-1}\right)$ for $24 \mathrm{~h}$. Cells were lysed in RIPA-IP buffer $(140 \mathrm{~mm}$ $\mathrm{NaCl}, 20 \mathrm{~mm}$ Tris/HCl, $10 \mathrm{~mm}$ EDTA pH 8, 10\% glycerol, $1 \%$ NP40, $1 \mathrm{~mm}$ Na-deoxycolic acid, $1 \mathrm{~mm}$ phenylmethylsulphonyl fluoride (PMSF)), passed through a 22-gauge syringe and cleared by centrifugation at $10000 \mathrm{~g}$ at $4^{\circ} \mathrm{C}$ for $10 \mathrm{~min}$. Proteins were immunoprecipitated by incubating $0.1-0.3 \mathrm{mg}$ of total cell lysate with $0.2 \mu \mathrm{g}$ of antiphosphotyrosine antibody or anti-EGFR antibody for $1 \mathrm{~h}$ at $4{ }^{\circ} \mathrm{C}$. In all, $2-5 \mu \mathrm{l}$ of protein A/G agarose (Santa Cruz Biotechnology, USA) were incubated overnight at $4^{\circ} \mathrm{C}$. Cell suspension was centrifuged at 2600 r.p.m. and the pellet was washed three times with phosphate-buffered saline (PBS) and then resuspended in $10 \mu \mathrm{l}$ of Laemmli buffer. Each sample was separated on $10 \%$ acrylamide gel and Western blot was performed as described above.

\section{Apoptosis analysis}

Apoptosis detection was performed by Annexin V-FITC staining assays (Biovision, Palo Alto, CA, USA). In accordance with the manufacturer's instructions, HCC cells $\left(5 \times 10^{5}\right)$ were incubated with Annexin V at room temperature for $10 \mathrm{~min}$. Apoptotic cells were detected by FACS analysis (Becton-Dickinson, NJ, USA) and quantified using cellquest software (Becton-Dickinson).

Apoptosis detection was further investigated by the Cell Death ELISA $^{\text {PLUS }}$ kit (Roche Molecular Biochemicals, Milan, Italy). The test is based on the detection of mono- and oligonucleosomes in the cytoplasmic fraction of cell lysates by biotinylated antihistonecoupled antibodies, and their enrichment in the cytoplasm is calculated as the absorbance of sample cells/absorbance of control cells. The enrichment factor was used as a parameter of apoptosis and shown on the $Y$-axis as mean \pm standard deviation (s.d.). Experiments were performed according to the manufacturer's instructions.

\section{Statistical analysis}

Results are expressed as the mean \pm s.d. and the statistical significance of the Ln-5-dependent reduction of gefitinib activity was determined by Student's $t$-test with a $95 \%$ confidence interval.

\section{RESULTS}

All the experiments of gefitinib-induced cytotoxicity were evaluated after 3 days of continuous exposure, therefore the use of FCS in the in vitro culture system was required to ensure cell vitality; this is consistent with other studies (Magne et al, 2003; Tortora et al, 2003; Xu et al, 2003b). Furthermore, we have previously shown the stability of the drug in the presence of serum in the HPLC system (Porcelli et al, 2004).

\section{Epidermal growth factor receptor and downstream effectors expression on HCC cell lines}

As shown in Figure 1, the expression level of EGFR is higher in HLF and Sk-Hep1 cells than in Alexander and HepG2 cells, while 
Table I Gefitinib IC 50 in HCC cell lines after 3 days incubation

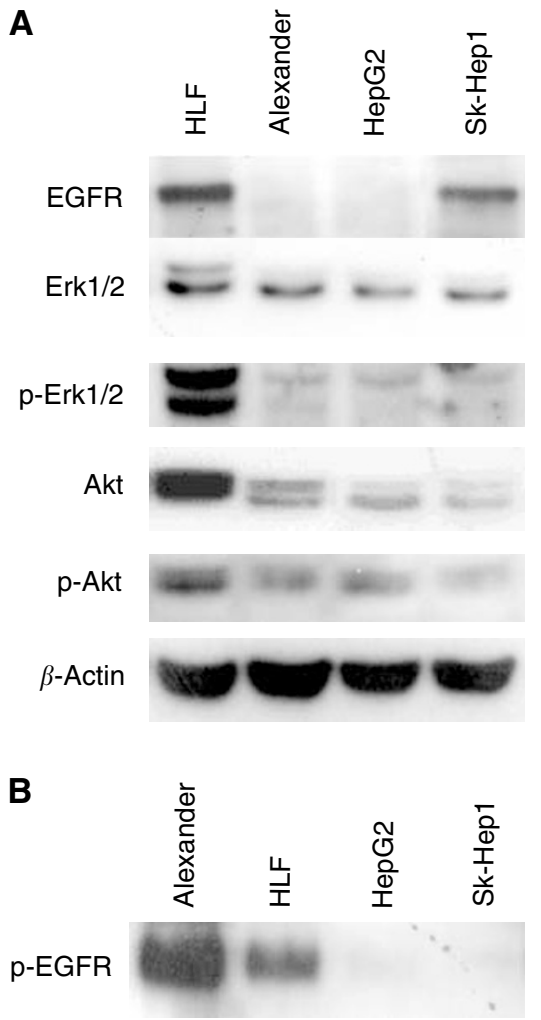

Figure I EGFR and downstream effectors expression on $\mathrm{HCC}$ cell lines. EGFR, Erk I/2, p-Erk 1/2, Akt, p-Akt expression in HLF, Alexander, HepG2 and Sk-Hepl cellular extracts were analysed by Western blotting $(\mathbf{A})$. Phosphorylated-EGFR was determined by immunoprecipitation followed by Western blotting (B).

the p-EGFR form is more evident in Alexander and HLF cells than in HepG2 and Sk-Hep1 cells. On the contrary, no differences were observed between HCC cell lines in terms of Erk 1/2, p- Erk 1/2, Akt and p-Akt expression.

\section{Gefitinib inhibits HCC cell lines growth}

To provide preclinical evidence of the effectiveness of gefitinib in HCC, we tested the sensitivity of four distinct human HCC cell lines to different drug concentrations after 3 days incubation, consistent with a long period of drug utilisation in clinical trials.

All the cell lines were investigated under the same experimental conditions to limit biological variability. As reported in Table 1, HCC cell lines showed similar gefitinib $\mathrm{IC}_{50}$ values. Experiments were repeated at least three times, and the mean and standard deviation refer to all the experiments.

\section{Extracellular matrix proteins modulate gefitinib effectiveness}

To investigate whether ECM proteins such as Ln-1, Ln-5, Coll I, Coll IV, Fg, Fn and Vn can interfere with gefitinib's ability to inhibit cell growth of HCC cell lines, we added exogenous matrices $\left(1 \mu \mathrm{g} \mathrm{ml}^{-1}\right)$ to the cells in the presence of gefitinib $\mathrm{IC}_{50}$. As shown in Table 2, gefitinib-dependent cell cytotoxicity (50\%) was dramatically reduced by the presence of $\mathrm{Ln}-5$, with a consequent significant increase of cell survival $(P<0.001)$, whereas no effect was observed with any of the other ECM proteins used. However, this Ln- 5 activity was completely inhibited by anti- $\alpha 3$ but not by anti- $\alpha 6$ integrin-blocking antibodies in HLF cells, and was

\begin{tabular}{lc}
\hline Cell lines & Gefitinib $(\boldsymbol{\mu} \mathbf{M})$ \\
\hline Alexander & $0.67 \pm 0.22$ \\
HepG2 & $4.73 \pm 0.42$ \\
HLF & $4.04 \pm 0.54$ \\
Sk-Hepl & $10.1 \pm 1.76$ \\
\hline
\end{tabular}

Table 2 Percentage of survived HCC cells treated with Gefitinib $\left(\mathrm{IC}_{50}\right)$ in the presence of ECM proteins

\begin{tabular}{lcccc}
\hline & Sk-HepI & Alexander & HLF & HepG2 \\
\hline Gefitinib & $50 \pm 3.7$ & $50 \pm 1.3$ & $50 \pm 8.4$ & $50 \pm 10$ \\
Gefitinib+LN-5 & $78 \pm 6.9$ & $84 \pm 11.0$ & $81 \pm 5.8$ & $81 \pm 09$ \\
Gefitinib+Coll I & $62 \pm 6.9$ & $55 \pm 7.9$ & $56 \pm 9.5$ & $58 \pm 6.8$ \\
Gefitinib+Coll IV & $63 \pm 7.0$ & $57 \pm 2.3$ & $58 \pm 9.2$ & $61 \pm 5.9$ \\
Gefitinib+Fib & $61 \pm 6.6$ & $55 \pm 4.8$ & $57 \pm 6.2$ & $59 \pm 7.9$ \\
Gefitinib+FN & $62 \pm 5.4$ & $57 \pm 1.8$ & $55 \pm 8.3$ & $59 \pm 6.9$ \\
Gefitinib+LN-I & $57 \pm 9.7$ & $54 \pm 2.7$ & $59 \pm 5.0$ & $55 \pm 4.7$ \\
Gefitinib+VN & $59 \pm 7.5$ & $58 \pm 1.0$ & $56 \pm 5.6$ & $57 \pm 6.8$ \\
\hline
\end{tabular}

Each experiment was carried out in triplicate.

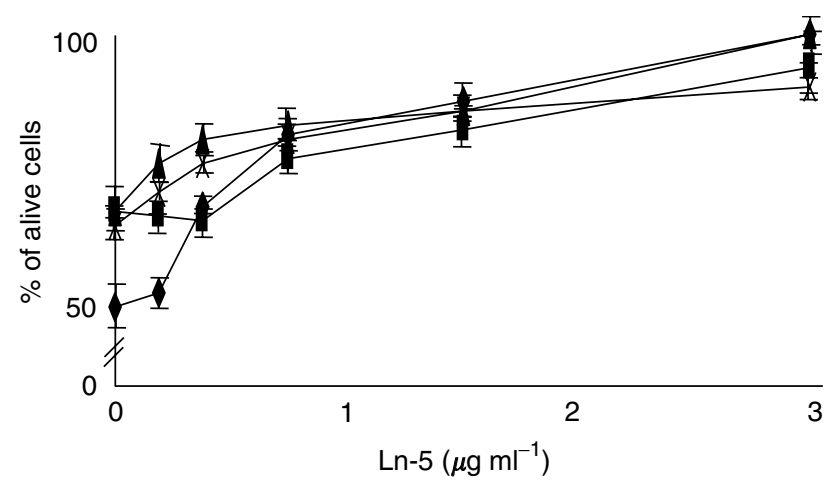

Figure 2 Ln-5 modulation of Gefitinib IC 50 effectiveness on HCC cells is dose-dependent. $L n-5$ inhibits Gefitinib $\mid C_{50}$ effectiveness at $\left.3 \mu \mathrm{gml}\right|^{-1}$ while it is not effective at $0.03 \mu \mathrm{g} \mathrm{ml}^{-1}$ on HLF $(\bullet)$, Alexander $(\mathbf{\square})$, SkHepl ( $\mathbf{\Delta})$ and HepG2 (X) cells.

completely inhibited by anti- $\alpha 6$ in Alexander cells. These results are consistent with our previous work reporting a strong expression of $\alpha 3$ integrin in HLF, while Alexander cells were $\alpha 3$ integrin negative but intensely $\alpha 6$ positive (Giannelli et al, 2001).

To better characterise the interaction of Ln-5 with gefitinib treatment, HCC cell lines were incubated with gefitinib $\left(\mathrm{IC}_{50}\right)$ in the presence of different Ln-5 concentrations. As shown in Figure 2, gefitinib's ability to inhibit cell growth was Ln-5 dose-dependent; in particular, complete inhibition of the drug-induced effect was obtained with $3 \mu \mathrm{g} \mathrm{ml}^{-1}$ of $\mathrm{Ln}-5$, while no changes were observed with $0.03 \mu \mathrm{g} \mathrm{ml}^{-1}$ of Ln-5.

In conclusion, gefitinib inhibited growth of HCC cell lines, whereas Ln-5 inhibited the gefitinib-induced activity in a dosedependent manner.

\section{Cellular response to gefitinib and/or Ln-5}

Molecular targets To study the molecular mechanisms responsible for the interaction between gefitinib and Ln-5, we analysed the modulation of drug-specific cell targets such as EGFR, as well 
as the main steps of its signal transduction pathways, including Erk1/2 and Akt.

Neither gefitinib nor Ln-5 affected EGFR, Akt and Erk1/2 expression compared to controls using $\beta$-actin expression as internal standard.

On the contrary, the p-EGFR form was completely inhibited after $6 \mathrm{~h}$ of drug treatment $\left(\mathrm{IC}_{50}\right)$ and recovered after 1 day, while no effect was observed after the addition of Ln-5 (Figure 3). Consistently, p-Erk 1/2 and p-Akt were both inhibited, with some differences between Alexander and HLF cells. After a short time of drug exposure $(6 \mathrm{~h})$, gefitinib inhibited both effectors more efficiently in Alexander than in HLF cells (Figure 4). No effect of Ln-5 alone was observed on either effector, whereas Ln-5-treated cells showed a reduced gefitinib inhibition of p-Akt from 15 to $25 \%$ $(P>0.05)$ and from 25 to $35 \%(P>0.05)$ in Alexander and HLF cells, respectively, and of p-Erk1/2 from 2 to $20 \%(P=0.02)$ and from 60 to $80 \%(P=0.03)$ in Alexander and HLF cells, respectively.

After $24 \mathrm{~h}$ of gefitinib and/or Ln-5 exposure, no differences between Alexander and HLF cells were evident. As shown in Figure 5, p-Erk1/2 returned to baseline even in the absence of Ln-5, whereas p-Akt inhibition decreased, in the presence of Ln-5, from 70 to $30 \%(P<0.02)$ and from 60 to $20 \%(P<0.02)$ in Alexander

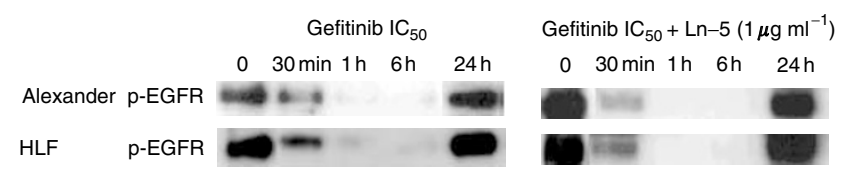

Figure 3 Time course of Gefitinib-dependent p-EGFR inhibition in HCC cells in the presence and absence of Ln-5. p-EGFR is completely inhibited after $6 \mathrm{~h}$ and completely recovers after $24 \mathrm{~h}$ both in the presence and absence of Ln-5.

and HLF cells, respectively. In conclusion, the recover of the effector forms in the presence of Ln-5 is time-dependent.

\section{Apoptosis induction}

Apoptotic cells were quantified using Annexin V and cytoplasmic histone-associated-DNA fragmentation assays. After three days of gefitinib exposure, there were 7 and $5 \%$ Annexin $\mathrm{V}$ positive cells and the mono- and oligonucleosomes enrichment factor was $4.3 \pm 0.4$ and $3.8 \pm 0.2$, in Alexander and HLF cells, respectively. Consistently with the Ln-5 effect on gefitinib-dependent p-Akt inhibition, in Ln-5-treated cells exposed to gefitinib treatment, Annexin-positive cells were less than $1 \%$ while the enrichment factor was less than $1.8 \pm 0.2$ in both cell lines.

\section{DISCUSSION}

Prognosis and survival of HCC patients is still poor. Nevertheless, no drug treatment is currently available to block or reduce cancer growth and/or tumour metastasis. This is mainly because the molecular mechanisms regulating the aggressive and malignant phenotype of HCC are still unknown. However, it has been reported that the expression of Ln-5 is strongly correlated with a worse prognosis in HCC patients (Giannelli et al, 2003). No therapies are so far available to inhibit or reduce HCC growth and invasion.

Gefitinib, a target-oriented drug that inhibits EGFR tyrosine kinase, has been successfully used to reduce lung and colon cancer growth and metastasis (Sirotnak, 2003; Xu et al, 2003a, b; Azzariti et al, 2004). Recently, it has been reported that gefitinib reduces tumour growth and metastatic spread of HCC in a mouse experimental model (Matsuo et al, 2003). Furthermore, a Phase
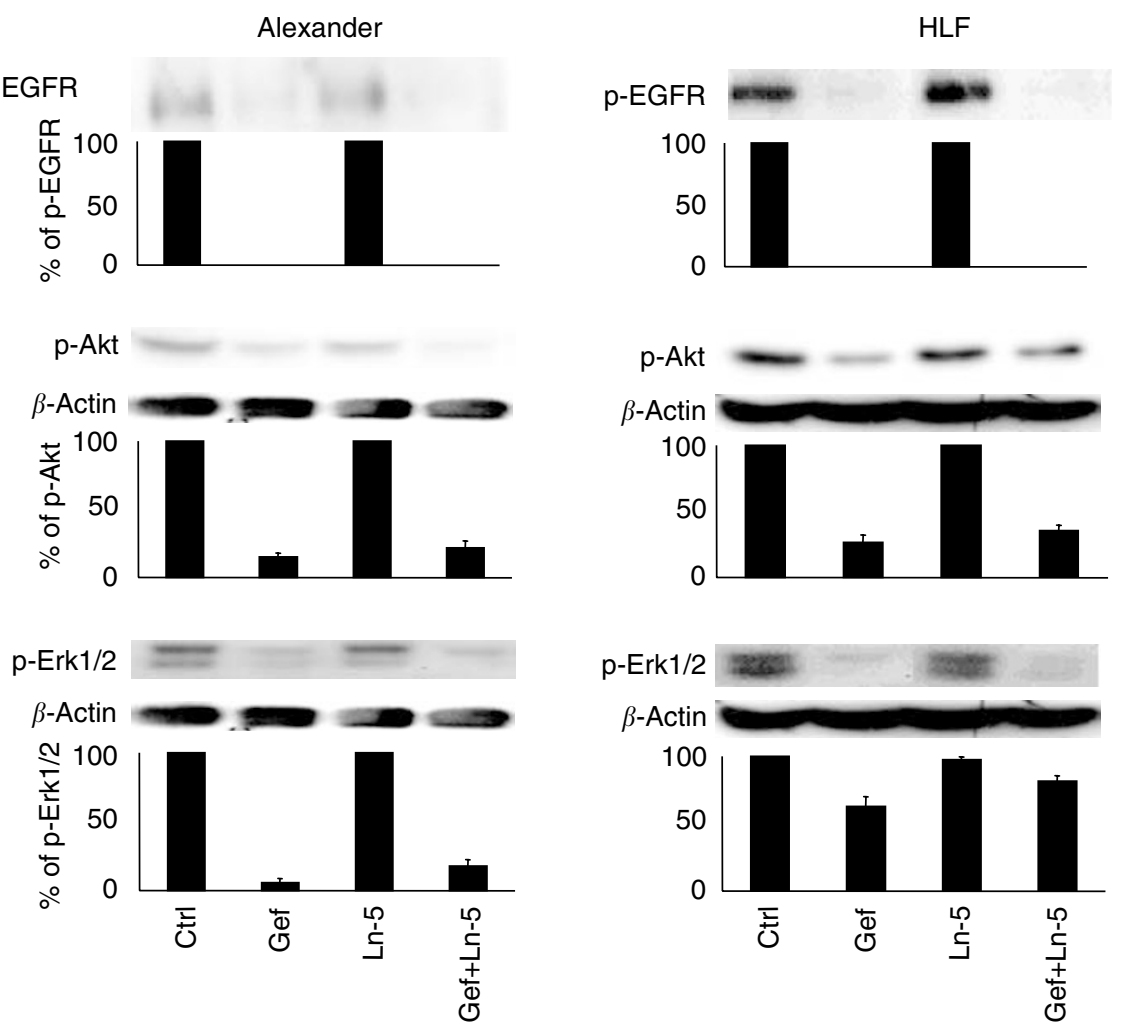

Figure 4 Ln-5 modulation of $6 \mathrm{~h}$ Gefitinib activity on molecular targets. Ln-5 (I $\left.\mu \mathrm{g} \mathrm{ml^{-1 }}\right)$ does not reverse Gefitinib (IC 50$)$ effectiveness on p-EGFR, but partially restores $\mathrm{p}$-Akt and $\mathrm{p}$-Erk I/2 on Alexander and HLF cells. 

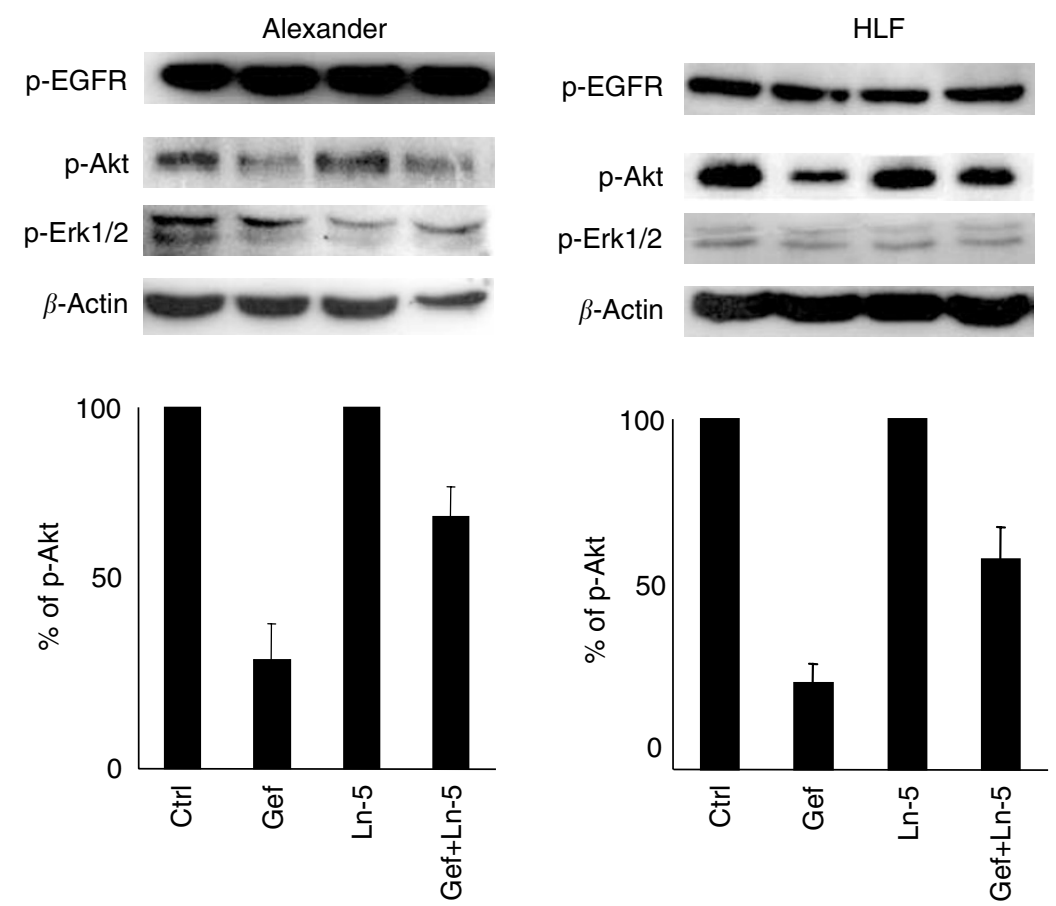

Figure 5 Ln-5 modulation of $24 \mathrm{~h}$ Gefitinib activity on p-Akt. Gefitinib $\left(\mathrm{IC}_{50}\right)$ does not affect p-EGFR and p-Erk I/2 on Alexander and HLF cells. With Ln-5 $\left(\mathrm{l} \mu \mathrm{g} \mathrm{ml}^{-1}\right), \mathrm{p}$-Akt recovers (40\%) in both cell lines.

II trial with gefitinib in patients with HCC is currently ongoing in the USA; however, no data are yet available on HCC cell sensitivity.

In this study, we investigated the effectiveness of an in vitro HCC model to gefitinib. Our results show that gefitinib is effective on HCC growth, but its activity is inhibited by Ln-5. We base this conclusion on the following data: (1) gefitinib inhibits HCC cell growth; (2) Ln-5 antagonises gefitinib growth inhibition in a dosedependent manner; (3) gefitinib induces persistent dephosphorylation of Akt, while with Ln-5 the p-Akt form recovers; (4) gefitinib-induced late apoptosis is reversed by Ln- 5 .

In other cancers, such as colon and lung carcinoma, the downstream effect of inhibiting EGFR phosphorylation involves both the Akt and Erk1/2 pathways (Azzariti et al, 2004), but unlike other cancer systems, in the HCC model, there is transient inhibition of the proliferation pathway ( $\mathrm{p}$-Erk1/2), while there is persistence of the survival pathway (p-Akt), inducing cell growth inhibition and apoptosis.

Moreover, we reported that the effect of gefitinib on its downstream effectors, p-Akt and p-Erk1/2, is time-dependently reversed by Ln-5, which is expressed de novo in HCC but not in peritumoral or normal tissues (Giannelli et al, 2003), whereas no effects are observed with other ECM molecules such as Ln-1, Coll I, Coll IV, Fn, Fg and Vn. To our knowledge, this is the first evidence of an ECM molecule inhibiting the effectiveness of gefitinib, although protection from apoptosis by ECM proteins has been reported in small-cell lung carcinoma (Sethi et al, 1999) (Table 2).

Thus, we could hypothesise that Ln-5 expression could be a predictive factor for gefitinib response in HCC. Moreover, since Ln-5 is widely distributed in human tissues including lung and colon, our data could contribute to explain differential responsiveness to gefitinib (Haringhuizen et al, 2004). The mechanisms responsible for the recovery of the p-Akt form are still unknown and require further investigation; however, we can role out the possibility that Ln-5 physically interacts with gefitinib since pEGFR is inhibited even in the presence of Ln-5. Furthermore, in our model, it is very likely that both the $\alpha 6 \beta 4$ and $\alpha 3 \beta 1$ integrins are involved in the Ln-5 signal pathway since both anti- $\alpha 3-$ and anti- $\alpha 6$-blocking antibodies inhibit Ln-5-mediated survival in cytotoxicity experiments. Thus, consistently with our previous work (Giannelli et al, 2001), in the HCC model, it is possible that either $\alpha 3 \beta 1$ or $\alpha 6 \beta 4$ are implicated in signal transduction, mainly depending on which receptor is predominantly expressed. Therefore, these data could contribute to explain the discrepancy in the literature between the involvement of $\alpha 3 \beta 1$ and $\alpha 6 \beta 4$ in cancer aggressiveness.

In conclusion, gefitinib inhibited cell growth in all the human HCC cell lines studied. Furthermore, for the first time, we have shown that a widely distributed ECM molecule, namely Ln-5, inhibits gefitinib's ability to inhibit cell growth. For HCC patients, differential expression levels of Ln-5 may help to understand which patients might benefit from gefitinib treatment.

\section{ACKNOWLEDGEMENTS}

This study was supported by the Italian Association Cancer Research (AIRC) (grant to GG).

\section{REFERENCES}

Azzariti A, Xu JM, Porcelli L, Paradiso A (2004) The schedule-dependent enhanced cytotoxic activity of 7-ethyl-10-hydroxy-camptothecin (SN-38) in combination with Gefitinib (Iressa trade mark, ZD1839). Biochem Pharmacol 68: $135-144$ 
Baker SE, Hopkinson SB, Fitchmun M, Andreason GL, Frasier F, Plopper G, Quaranta V, Jones JC (1996) Laminin-5 and hemidesmosomes: role of the alpha 3 chain subunit in hemidesmosome stability and assembly. J Cell Sci 109(Part 10): 2509-2520

Bruix J, Llovet JM (2002) Prognostic prediction and treatment strategy in hepatocellular carcinoma. Hepatology 35: 519-524

Douglass EC (2003) Development of ZD1839 in colorectal cancer. Semin Oncol 30: $17-22$

Felding-Habermann B, Fransvea E, O’Toole TE, Manzuk L, Faha B, Hensler $M$ (2002) Involvement of tumor cell integrin alpha $\mathrm{v}$ beta 3 in hematogenous metastasis of human melanoma cells. Clin Exp Metast 19: $427-436$

Fukuoka M, Yano S, Giaccone G, Tamura T, Nakagawa K, Douillard JY, Nishiwaki Y, Vansteenkiste J, Kudoh S, Rischin D, Eek R, Horai T, Noda K, Takata I, Smit E, Averbuch S, Macleod A, Feyereislova A, Dong RP, Baselga J (2003) Multi-institutional randomized phase II trial of gefitinib for previously treated patients with advanced non-small-cell lung cancer. J Clin Oncol 21: 2237-2246

Giannelli G, Astigiano S, Antonaci S, Morini M, Barbieri O, Noonan DM, Albini A (2002a) Role of the alpha3betal and alpha6beta4 integrins in tumor invasion. Clin Exp Metast 19: 217-223

Giannelli G, Bergamini C, Fransvea E, Marinosci F, Quaranta V, Antonaci S (2001) Human hepatocellular carcinoma (HCC) cells require both alpha3beta1 integrin and matrix metalloproteinases activity for migration and invasion. Lab Invest 81: 613-627

Giannelli G, Fransvea E, Bergamini C, Marinosci F, Antonaci S (2003) Laminin-5 chains are expressed differentially in metastatic and nonmetastatic hepatocellular carcinoma. Clin Cancer Res 9: 3684-3691

Giannelli G, Pierri F, Trerotoli P, Marinosci F, Serio G, Schiraldi O, Antonaci S (2002b) Occurrence of portal vein tumor thrombus in hepatocellular carcinoma affects prognosis and survival. A retrospective clinical study of 150 cases. Hepatol Res 24: 50-59

Haringhuizen A, Van Tinteren H, Vaessen HF, Baas P, Van Zandwijk N (2004) Gefitinib as a last treatment option for non-small-cell lung cancer: durable disease control in a subset of patients. Ann Oncol 15: 786-792

Herbst RS (2003) Dose-comparative monotherapy trials of ZD1839 in previously treated non-small cell lung cancer patients. Semin Oncol 30: $30-38$

Johnson DH, Fehrenbacher L, Novotny WF, Herbst RS, Nemunaitis JJ, Jablons DM, Langer CJ, DeVore III RF, Gaudreault J, Damico LA, Holmgren E, Kabbinavar F (2004) Randomized phase II trial comparing bevacizumab plus carboplatin and paclitaxel with carboplatin and paclitaxel alone in previously untreated locally advanced or metastatic non-small-cell lung cancer. J Clin Oncol 22: 2184-2191

Koshikawa N, Giannelli G, Cirulli V, Miyazaki K, Quaranta V (2000) Role of cell surface metalloprotease MT1-MMP in epithelial cell migration over laminin-5. J Cell Biol 148: 615-624
Kris MG, Natale RB, Herbst RS, Lynch Jr TJ, Prager D, Belani CP, Schiller JH, Kelly K, Spiridonidis H, Sandler A, Albain KS, Cella D, Wolf MK, Averbuch SD, Ochs JJ, Kay AC (2003) Efficacy of gefitinib, an inhibitor of the epidermal growth factor receptor tyrosine kinase, in symptomatic patients with non-small cell lung cancer: a randomized trial. JAMA 290: 2149-2158

Magne N, Fischel JL, Tiffon C, Formento P, Dubreuil A, Renee N, Formento JL, Francoual M, Ciccolini J, Etienne MC, Milano G (2003) Molecular mechanisms underlying the interaction between ZD1839 ('Iressa') and cisplatin/5-fluorouracil. Br J Cancer 89: 585-592

Matsuo M, Sakurai H, Saiki I (2003) ZD1839, a selective epidermal growth factor receptor tyrosine kinase inhibitor, shows antimetastatic activity using a hepatocellular carcinoma model. Mol Cancer Ther 2: 557-561

Meneguzzi G, Marinkovich MP, Aberdam D, Pisani A, Burgeson R, Ortonne JP (1992) Kalinin is abnormally expressed in epithelial basement membranes of Herlitz's junctional epidermolysis bullosa patients. Exp Dermatol 1: 221-229

Miyazaki K, Kikkawa Y, Nakamura A, Yasumitsu H, Umeda M (1993) A large cell-adhesive scatter factor secreted by human gastric carcinoma cells. Proc Natl Acad Sci USA 90: 11767-11771

Porcelli L, Azzariti A, Xu JM, Simone GM, Paradiso A (2004) Exposure of HT-29 and LoVo cells to the EGFR tyrosine kinase inhibitor gefitinib (Iressa $^{\mathrm{TM}}, \mathrm{ZD1839}$ ) and the antiangiogenic agent ZD6474: modulation of tyrosine kinase receptors and their signal transduction pathway. Proceedings of the American Association Cancer Research 5th Annual Meeting, Orlando, vol. 45, p 1075 (abstract number 4655)

Sethi T, Rintoul RC, Moore SM, MacKinnon AC, Salter D, Choo C, Chilvers ER, Dransfield I, Donnelly SC, Strieter R, Haslett C (1999) Extracellular matrix proteins protect small cell lung cancer cells against apoptosis: a mechanism for small cell lung cancer growth and drug resistance in vivo. Nat Med 5: $662-668$

Sirotnak FM (2003) Studies with ZD1839 in preclinical models. Semin Oncol 30: $12-20$

Tortora G, Caputo R, Damiano V, Melisi D, Bianco R, Fontanini G, Veneziani BM, De Placido S, Bianco AR, Ciardiello F (2003) Combination of a selective cyclooxygenase-2 inhibitor with epidermal growth factor receptor tyrosine kinase inhibitor ZD1839 and protein kinase A antisense causes cooperative antitumor and antiangiogenic effect. Clin Cancer Res 9: $1566-1572$

Xia Y, Gil SG, Carter WG (1996) Anchorage mediated by integrin alpha6beta4 to laminin 5 (epiligrin) regulates tyrosine phosphorylation of a membrane-associated 80-kDa protein. J Cell Biol 132: 727-740

Xu JM, Azzariti A, Colucci G, Paradiso A (2003a) The effect of gefitinib (Iressa, ZD1839) in combination with oxaliplatin is schedule-dependent in colon cancer cell lines. Cancer Chemother Pharmacol 52: 442-448

Xu JM, Azzariti A, Severino M, Lu B, Colucci G, Paradiso A (2003b) Characterization of sequence-dependent synergy between ZD1839 ('Iressa') and oxaliplatin. Biochem Pharmacol 66: 551-563 